\title{
БИОЛОГИЧЕСКИЕ ОСОБЕННОСТИ КАПУСТНЫХ ОВОЩНЫХ КУЛЬТУР ВИДА Brassica rapa L. ПРИ ВЫРАЩИВАНИИ В ИНТЕНСИВНОЙ СВЕТОКУЛЬТУРЕ
}

\author{
А.М. АРТЕМЬЕВА $1,2 \bowtie$, Н.Г. СИНЯВИНА 2 , Г.Г. ПАНОВА 2 Ю.В. ЧЕСНОКОВ 2
}

Одна из основных составляющих успешного производства растительной продукции выбор культур с высокой реализацией продукционного потенциала в формируемых условиях, в том числе в условиях интенсивной светокультуры. Задача компенсации или ликвидации дефицита зеленных культур в настоящее время в России и мире стоит достаточно остро. Генетическое разнообразие распространенных в использовании в сооружениях защищенного грунта капустных зеленных растений вида репа Brassica rapa L. сложилось в Юго-Восточной Азии и включает многочисленные морфотипы пекинской, китайской, розеточной, пурпурной, японской капусты, листовой репы. В России капустные овощи вида репа используют ограниченно, главным образом в качестве салатных овощей. Основные направления селекции представителей вида $B$. rapa для светокультуры включают высокую скорость роста (продолжительность одного оборота не более 28-35 сут в зависимости от биологических особенностей культуры), урожайность не менее 3-8 кг/м² в зависимости от культуры, компактный габитус растения, высокое качество листьев, ценный биохимический состав, устойчивость к раннему стеблеванию, устойчивость к возможной пониженной освещенности и повышенной температуре воздуха, пригодность для выращивания в тонком слое почвенного субстрата или на гидропонике. Биологические особенности разнообразия капустных культур вида репа как источников при селекции для условий светокультуры изучены недостаточно, прежде всего это касается малоизвестных культур (розеточная, пурпурная, японская капусты) и отдельных морфотипов в пределах распространенных культур (пекинская и китайская капусты). В настоящем исследовании мы впервые изучили широкое генетическое разнообразие мировой коллекции культур вида B. rapa Российской Федерации, хранящейся в ВИР, и морфотипов внутри них (72 образца), включая контрастные по морфологическим признакам генотипы, при разной обеспеченности светом с целью развития энергосберегающих агротехнологий в интенсивной светокультуре. Впервые определены поправочные коэффициенты для расчета площади листовой поверхности по легко измеряемым линейным размерам для каждой изученной культуры и типа листьев, что позволит ускорить расчеты фотосинтетических характеристик. Показана различная степень изменчивости размеров и массы растений культур в зависимости от освещенности (наибольшая - у пекинской капусты и листовой репы). Установлено, что интенсивностью светового потока в значительной мере определяется повышение продуктивности растений всех капустных культур вида репа $B$. значительной степени - пекинской и китайской капусты и листовой репы. Выделены высокоурожайные образцы пекинской и китайской капусты и листовой репы (более 6,3 кг/м $\mathbf{m}^{2} 328$ сут вегетации). Изученные образцы пурпурной и японской капусты низкоурожайные и имеют более длительный вегетационный период, но представляют интерес в качестве овощей для функционального питания и для декоративных целей. Выявлены полукочанные сортотипы пекинской капусты (Шантунг, Санто, Сяо), представляющие преимущественный интерес для светокультуры. Для загущенного выращивания рекомендованы образцы пекинской капусты вр.к-1375, Бице (вр.к-1376), китайской капусты к-647, для выращивания при малом расстоянии между стеллажами (25 см) китайской капусты Extra Dwarf Pack Choi (вр.к-1405) и розеточной капусты Хіао Ва Је Та Саi (к-695). Образцы пекинской капусты Chokurei (к-177), Tokyo Bekana (к-395), Zao Shi № 5 (вр.к-1120), Fun јеn F1 (вр.к-1410) показали самые высокие салатные качества листьев. В условиях биополигона нам удалось выделить образцы со стабильным проявлением признаков скороспелости и высокой продуктивности, практически не зависящим от освещенности. Это образцы пекинской капусты Harumaki Shin Santousai (к-270), Tokyo Bekana (к-395), Сяобайкоу (к-74), китайской капусты Kangre 605 (вр.к-1131), Gai Lang Jin Pin 25 F1 (вр.к-1124). Кроме того, показано, что у китайского образца пекинской капусты Zao Shi № 5 (вр.к-1120) и российского сорта листовой репы Селекта (вр.к-1371) повышена активность фотосинтетического аппарата. Полученные данные о культурах в целом и выделившихся образцах $B$. для овощеводства, при разработке элементов сортовой технологии капустных культур в условиях светокультуры и в качестве источников ценных признаков в селекционных программах, в том числе по развитию сити-фермерства.

Ключевые слова: Brassica rapa L., листовые капустные культуры, интенсивная светокультура, ценные признаки, генетические источники.

Основное генетическое разнообразие самых распространенных капустных зеленных растений вида Brassica rapa L. (репа) для защищенного 
грунта сложилось в Юго-Восточной Азии - первоначально в Китае, затем в Японии и Корее. Оно включает многочисленные морфотипы пекинской, китайской, розеточной, пурпурной, японской капусты и листовой репы. Наиболее широко на земном шаре возделывается пекинская капуста, китайская капуста распространена в Центральном и Южном Китае, розеточная и пурпурная - в Южном Китае, японская капуста и листовая репа - в Японии (1).

Во многих индустриально развитых странах (Япония, США, Китай, Сингапур, Южная Корея, страны Евросоюза) быстрорастущие капустные листовые культуры, обладающие ценным биохимическим составом, помимо традиционных способов возделывания (открытый и защищенный грунт), выращивают наряду с салатом (Lactuca sativa L.) в светокультуре в условиях нового интенсивно развивающегося типа растительного производства - на вертикальных фермах (растительных фабриках) (2-7).

В России капустные овощи $B$. rapa традиционно используются ограниченно - главным образом в качестве салатных овощей. Пекинскую капусту выращивают в открытом и защищенном грунте, в том числе в промышленном овощеводстве. Хотя первый отечественный сорт пекинской капусты Хибинская был создан еще в 1962 году на Полярной опытной станции ВИР (г. Апатиты, Мурманская обл.) и возделывался широко, в дальнейшем в теплицах пекинская капуста уступила место салату. Китайскую и японскую капусты в России выращивают очень ограниченно в частном овощеводстве (первые сорта включены в Государственный реестр селекционных достижений, допущенных к использованию, соответственно в 2000 и 2002 году), листовая репа и розеточная капуста известны мало, пурпурная капуста неизвестна (Государственный реестр селекционных достижений, допущенных к использованию. Т. 1. Сорта растений. Официальное издание. М., 2020). При этом следует заметить, что все капустные культуры $B$. rapa обладают набором ценных признаков. Они скороспелые, продуктивные, холодостойкие, относительно просты в выращивании. По биохимическому составу эти культуры (особенно малораспространенные) превосходят салат (содержание витамина С - 40-80 мг/100 г, $\beta$-каротина 2-10 мг/100 г, хлорофиллов - 50-200 мг/100 г, большое количество органических кислот, фенольных соединений, красноокрашенные формы содержат антоцианы), чем обусловлен рост интереса к таким культурам (8-11).

В 2020 году в Государственный реестр селекционных достижений, допущенных к использованию (Т. 1. Сорта растений. М., 2020), включены 84 сорта и гибрида капустных культур вида B. rapa. Среди 57 образцов пекинской капусты $75 \%$ - гибриды $\mathrm{F}_{1}$, в том числе 19 - отечественной селекции, из 18 образцов китайской капусты 7 - гибриды, включая 5 российских, 5 образцов японской капусты и $4-$ листовой репы представлены в основном сортами отечественной селекции. Однако отметим, что тепличные хозяйства России пока что обеспечивают только половину необходимого объема зеленных культур. При этом в Госреестре отсутствуют сорта листовых капустных культур вида $B$. rapa, созданные специально для светокультуры.

Интенсивная светокультура находит все большее применение в мире и активно используется в современных сооружениях защищенного грунта, являясь неотъемлемым элементом урбанизированного сельскохозяйственного производства, развитие которого в ближайшие десятилетия, по данным экспертов, будет неуклонно нарастать. Это обусловлено его более высокой производительностью и эффективностью по использованию ресурсов - пространства, почвы, воды, по числу урожаев, по объему удобрений и т.д. (в 
15-90 раз выше по сравнению с открытым грунтом и в 1,5-10 раз - по сравнению с современными тепличными комплексами защищенного грунта) (2, $12,13)$, а также постепенным сокращением (по прогнозам ООН и ФАО) высокопродуктивных земель вследствие их поглощения растущими мегаполисами, выраженной тенденцией сосредоточения населения в городах и невозможностью обеспечить количественный и качественный спрос на продукты питания с помощью традиционной цепочки производства и поставок продовольствия $(14,15)$.

Одна из основных составляющих успешной работы урбанизированного растительного производства, особенно в случае энергозатратного производства с применением светокультуры, - выбор культур с высокой реализацией продукционного потенциала в формируемых условиях. Исследования влияния агротехнических особенностей выращивания в защищенном грунте и в светокультуре, в том числе уровня облученности и спектрального состава света, на продуктивность и биометрические показатели различных овощных культур проводятся в России (16-19) и за рубежом $(5,7,20-23)$, однако многие вопросы, связанные с обеспечением устойчивой рентабельности производства, до сих пор не решены.

Системная фундаментальная многолетняя исследовательская работа по физическому моделированию и изучению влияния факторов жизнеобеспечения культурных растений на их продукционный процесс, качество формируемой растительной продукции в регулируемых условиях проводится в нашей стране только в ряде НИИ, в том числе в Агрофизическом научноисследовательском институте, где на основе системного подхода осуществляются разработки по оптимизации методов получения стабильно высоких урожаев качественной растительной продукции в полностью формируемых условиях световой, воздушной, корнеобитаемой среды и в зависимости от агротехнологических факторов (24). Разработанные и испытанные на биополигоне института прообразы мобильных и стационарных растительных фабрик с оригинальными технологиями показали высокую эффективность и производительность (25).

Биологические особенности разнообразия капустных культур вида B. rapa мировой коллекции ВИР в условиях светокультуры изучены недостаточно. До сих пор не выработаны критерии отбора генотипов для выращивания в условиях интенсивной светокультуры, что необходимо при селекции форм для инновационного урбанизированного агропроизводства сити-фермерства. Прежде всего это касается малоизвестных в России культур (розеточная, пурпурная, японская капусты) и разных морфотипов в пределах распространенных культур (пекинская и китайская капусты).

В представленной работе впервые дана оценка широкого генетического разнообразия российской коллекции капустных культур и морфотипов внутри них у вида Brassica rapa L. по морфологическим и фенологическим признакам, связанным с продуктивностью, при разной светообеспеченности при интенсивной светокультуре. Оценена степень варьирования размеров и массы различных типов растений в зависимости от освещенности. Для каждой из изученных культур - пекинской, китайской, розеточной, пурпурной, японской капусты и листовой репы - выделены источники для селекции на урожайность, скороспелость, салатные качества, устойчивость к пониженной освещенности. Установлены поправочные коэффициенты для расчета площади листовой поверхности для каждой культуры и типа листьев, что позволит ускорить расчеты фотосинтетических характеристик. 
Целью работы было изучение ростовых реакций генетического разнообразия капустных культур в условиях разной освещенности при использовании малообъемных технологий выращивания растений в интенсивной светокультуре.

Методика. Выборка капустных культур вида Brassica rapa L. (репа) включала 72 образца разного происхождения (коллекция ВИР, ФИЦ Всероссийский институт генетических ресурсов растений им. Н.И. Вавилова), в том числе 36 образцов пекинской капусты, 23 - китайской капусты, 3 розеточной капусты, 3 - японской капусты, 2 - пурпурной капусты и 5 образцов листовой репы.

Растения выращивали в условиях регулируемой агроэкосистемы (разработка АФИ) в оригинальной ярусной вегетационной светоустановке (25), оснащенной лампами ДНа3-400 (ООО «Рефлакс», Россия) при коротком дне (12-часовой фотопериод) и двух режимах освещенности - 1520 клк (высокая) и 10-15 клк (низкая). Спектральный состав излучения ламп ДНа3-400 близок к солнечному свету с преобладанием длинноволнового диапазона (http://www.reflux.ru). Расстояние от лампы до поверхности почвы составляло 55 см, от лампы до вершины растения $-25-50$ см в зависимости от возраста растений и высоты розетки исследуемых образцов. Дневная температура окружающей среды $-24 \pm 2{ }^{\circ} \mathrm{C}$, ночная $-20 \pm 2{ }^{\circ} \mathrm{C}$.

В качестве субстрата использовали верховой торф с минеральными добавками (26), толщина корнеобитаемого слоя 3-4 см. Полив осуществляли ежедневно, трижды в неделю вместо водопроводной воды использовали корневую подкормку 0,5 н. раствором Кнопа. Посевы дважды прореживали, в 2-недельном возрасте (схема выращивания - 10×8 см, для некоторых образцов китайской, розеточной, пурпурной капусты и листовой репы - 10×5 см, два образца китайской капусты выращивали также по схеме $10 \times 10$ см). Повторность в каждом варианте - 12-20 растений.

Образцы китайской и розеточной капусты выращивали также в Пушкинских лабораториях ВИР в остекленной теплице в ранневесенний период (посев 1 марта) и в открытом грунте (посев 1 июля). Схема выращивания одинаковая при всех условиях.

Для биометрической оценки и статистической обработки данных анализировали по 5 растений на вариант. Уборку проводили на 28-е сут после посева пророщенными семенами. При уборке оценивали основные биометрические показатели: габитус и массу растения, число листьев, размеры листовой пластинки и черешка (27).

Коэффициент для определения площади различных типов листьев рассчитывали после обработки фотографий растений с разглаженными листьями в программе Adobe Photoshop («Adobe, Inc.», США). Площадь одного листа определяли как произведение длины и ширины листовой пластинки и коэффициента, рассчитанного для каждого образца, площадь листовой поверхности растения - как произведение полученной величины и числа листьев.

Статистическую обработку данных выполняли методом дисперсионного анализа с помощью программы STATISTICA v.12.0 («StatSoft Inc.», США). Определяли среднее значение каждого признака $(M)$, стандартную ошибку среднего ( $\pm \mathrm{SEM})$, НСР при 5 \% уровне значимости, коэффициенты вариации значений признаков, коэффициенты корреляции изучаемых признаков. Существенность различий между вариантами определяли по показателю наименьшей существенной разницы.

Результаты. В мировой коллекции ВИР находится более 1050 образцов всех морфотипов овощных листовых культур вида $B$. rapa, поступивших 
с 1924 года, в том числе 470 образцов пекинской капусты, 123 - китайской, 7 - пурпурной, 23 - розеточной, 21 - японской, 58 образцов листовой репы. Уникальность этой коллекции достигает 50 \%. При подборе из существующих сортов и создании специальных, позволяющих получать с единицы площади 10-12 урожаев в год, рентабельность их выращивания может быть очень высокой, несмотря на затраты на освещение в традиционных сооружениях защищенного грунта и в интенсивной светокультуре $(2,19,24)$.

Для выращивания в светокультуре представители В. гара должны обладать высокой скоростью роста (продолжительность одного оборота не более 28-35 сут в зависимости от биологических особенностей культуры), урожайностью не менее 3-8 кг/м², определенным габитусом растения (предпочтительнее прямостоячая листовая розетка высотой до 30 см, лучше ниже), высоким качеством листьев (отсутствие опушения или слабое опушение, нежная консистенция, хороший вкус, ценный биохимический состав), устойчивостью к раннему стеблеванию, устойчивостью к возможной пониженной освещенности и повышенной температуре воздуха, пригодностью для выращивания в тонком слое почвенного субстрата или на гидропонике.

У длиннодневных листовых капустных культур, используемых в России главным образом в качестве салатных, морфологические и физиологические особенности продукционного процесса, включая скорость перехода к цветению, в значительной степени зависят от продолжительности светового периода, освещенности, спектрального состава света, приспособительных реакций к произрастанию в неблагоприятных световых условиях, в том числе в светокультуре при относительно повышенной температуре (28).

Мы отобрали для изучения 72 образца капустных культур вида репа B. rapa, включая староместные образцы и образцы современной селекции, различного происхождения преимущественно из стран, где развито потребление культур этого вида и ведется их селекция (табл. 1). Предварительно было проведено морфологическое описание образцов коллекции при выращивании в поле и в зимней остекленной теплице Пушкинских лабораторий ВИР (г. Санкт-Петербург) (29) и выделены образцы, по комплексу признаков предположительно близкие к модели желаемого сорта для светокультуры. Число образцов каждой культуры в выборке зависело от существующего естественного разнообразия морфотипов культуры.

1. Происхождение и принадлежность к эколого-географическому сортотипу у образцов восточноазиатских капустных культур Brassica rapa L. из коллекции ВИР, отобранных для изучения (биополигон ФГБНУ АФИ, г. СанкТ-Петербург, 2019 год)

\begin{tabular}{|c|c|c|c|}
\hline Номер по каталогу & Название & Сортотип/подтип & Происхождение \\
\hline \multicolumn{4}{|c|}{ К а п у с т а п е к и нск а я Brassica rapa L. subsp. pekinensis (Lour.) Hanelt } \\
\hline $\mathrm{K}-74$ & Сяобайкоу & Сяо & Китай \\
\hline $\mathrm{K}-112$ & Round Shantung & Шантунг & Япония \\
\hline $\mathrm{K}-123$ & Сяобайкоу & Сяо & Китай \\
\hline K-126 & Kairyo chitose & Мацусима & Япония \\
\hline K-177 & Chokurei & Шантунг & Япония \\
\hline K-185 & Местный & Сяо & Китай \\
\hline $\mathrm{K}-201$ & Hsiao Pai kou pai tsai & Касин & Китай \\
\hline $\mathrm{K}-227$ & Пяча & Сяо & Казахстан \\
\hline $\mathrm{K}-230$ & Digeson & Сяо & Корея \\
\hline $\mathrm{K}-236$ & Без названия & Чосен & Монголия \\
\hline $\mathrm{K}-252$ & Без названия & Санто & Япония \\
\hline $\mathrm{K}-270$ & Harumaki Shin Santousai & Санто & Япония \\
\hline K-294 & Xin feng 2 & Шантунг & Китай \\
\hline K-306 & Зеленая маленькая 1 & Касин & Корея \\
\hline K-307 & Осенняя 3 & Касин & Корея \\
\hline K-309 & Chammad-baechu & Чосен & Корея \\
\hline
\end{tabular}




\begin{tabular}{|c|c|c|c|}
\hline & & Прод & $\begin{array}{l}\text { олжеение таблицы } 1 \\
\text { Корея }\end{array}$ \\
\hline $\begin{array}{l}K-311 \\
\mathrm{~K}-329\end{array}$ & $\begin{array}{l}\text { Пхеньян } 2 \\
\text { Maruba Santo }\end{array}$ & $\begin{array}{l}\text { Касин } \\
\text { Санто }\end{array}$ & $\begin{array}{l}\text { Корея } \\
\text { Япония }\end{array}$ \\
\hline $\mathrm{K}-359$ & Нагаока F1 Адзума & Шантунг & Япония \\
\hline K-387 & Без названия & Сяо & Китай \\
\hline K-395 & Tokyo Bekana & Санто & Япония \\
\hline $\mathrm{K}-406$ & Shantung Tropical Round $\left(\mathrm{F}_{1}\right)$ & Шантунг & Япония \\
\hline $\mathrm{K}-410$ & Shirokuki Santousai & Санто & Япония \\
\hline $\mathrm{K}-440$ & Hakata Chirimen & Чиримен & Япония \\
\hline $\mathrm{K}-457$ & Осенняя 2 & Чосен & Корея \\
\hline K-497 & № 55 & Касин & Китай \\
\hline K-578 & Тепличная 56 & Касин & Китай \\
\hline $\mathrm{K}-629$ & Yoko $F_{1}$ & Дацинкоу & Нидерланды \\
\hline K-645 & Beijing xiaoza 56 & Касин & Китай \\
\hline вр.к-965 & Кикунисики F1 & Кага & Япония \\
\hline вр.к-1120 & Zao Shi № 5 & Шантунг & Китай \\
\hline вp.K-1375 & Без названия & Чосен & Киргизия \\
\hline вр.к-1376 & Бице & Санто $\times$ Хэтоу & Киргизия \\
\hline вр.К- 1400 & Chirimen Hakusai & Чиримен & США \\
\hline вр.к- 1410 & Fun jen $\mathrm{F}_{1}$ & Санто & США \\
\hline вр.к- 1557 & Mini Raioh F1 50 & Мацусима & Япония \\
\hline & К ап у с т а ки та й с кая Brassica rapc & $a$ L. subsp. chinensis (L.) Hanel & \\
\hline K-116 & Taisai & Тайсай & Япония \\
\hline $\mathrm{K}-470$ & $F_{1}$ Mei Qing Choi & Сыюсман & Нидерланды \\
\hline $\mathrm{K}-529$ & Зеленая 9 & Сыюсман & Китай \\
\hline $\mathrm{K}-538$ & Green Boy & Пиорбай & Китай \\
\hline $\mathrm{K}-558$ & Joi Choi & Джой чой & Китай \\
\hline $\mathrm{K}-583$ & 94 № 6 & Китайская $\times$ розеточная & Китай \\
\hline $\mathrm{K}-584$ & Xia L V № 2 Pakchoi & Сыюсман & Китай \\
\hline $\mathrm{K}-585$ & Lingguan № 1 PC & Сыюсман & Китай \\
\hline $\mathrm{K}-647$ & Без названия & Тайсай & Таджикистан \\
\hline вр.к-932 & Pack Choi $F_{1}$ & Пиорбай & Япония \\
\hline вр.к-1107 & Heiye kuishantian & Китайская $\times$ розеточная & Китай \\
\hline вр.к-1124 & Gai Lang Jin Pin $25 F_{1}$ & Сыюсман & Китай \\
\hline вр.К-1128 & Hanging & Сыюсман & Китай \\
\hline вр.к- 1130 & Wuyemanyoucai & Сыюсман & Китай \\
\hline Bp.K-1131 & Kangre 605 & Сыюсман & Китай \\
\hline вр.К-1251 & Без названия & Сыюсман & Китай \\
\hline вр.к-1343 & Shatu & Сыюсман & Китай \\
\hline вр.к-1403 & Chinese Pack Choi & Пиорбай & США \\
\hline вр.К-1404 & Dwarf Pack Choi & Джой чой & США \\
\hline вр.к-1405 & Extra dwarf Pack Choi & Джой чой & США \\
\hline вp.K-1406 & Petite star $F_{1}$ & Беби сыюсман & США \\
\hline вр.К-1408 & Red choi $\mathrm{F}_{1}$ & Сыюсман × Пиорбай & США \\
\hline вр.к-1521 & Без названия & Лейчой & Киргизия \\
\hline & Капуста розеточная Brassica rapa & L. subsp. narinosa (Bailey) Hal & Inelt \\
\hline K-695 & Xiao Ba Je Ta Cai & Тацай & Китай \\
\hline вр.к-1398 & Yukina Savoy & Хризантемум & США \\
\hline вр.к-1409 & Red tatsoi F1 & Тацай & США \\
\hline & Қапуста пурпурн а я Brassica rapa L. subsp. & chinensis (L.) Hanelt var. pupu & ıraria Kitam \\
\hline вр.к- 1357 & Без названия & Без названия & Нидерланды \\
\hline вр.к-1358 & Без названия & Без названия & Неизвестно \\
\hline & Капу ста япон с кая Brassica rapa $\mathrm{L}$. & subsp. nipposinica (Bailey) Han & \\
\hline $\mathrm{K}-463$ & Shirojuki Sensujo Kyo Mizuna Nakate & Мизуна & Япония \\
\hline $\mathrm{K}-506$ & Сэнсудзи Кио Мидзуна & Мизуна & Япония \\
\hline вр.к- 1360 & Без названия & Мизуна пурпурная & Нидерланды \\
\hline & Л и с т о в а я ре п а Brassica rapa L. subsp. $r c$ & rapifera Hook. var. komatsuna $\mathrm{M}$ & Makino \\
\hline K-335 & Hiroshimana & Хирошимана & Япония \\
\hline K-598 & Dapungru datou baixinie & Китайская $\times$ листовая репа & Китай \\
\hline вр.к-1371 & Селекта & Комацуна & Россия \\
\hline вр.к-1372 & Бирюза & Комацуна & Россия \\
\hline вр.к-1418 & Komatsuna & Комацуна & США \\
\hline
\end{tabular}

Исследуемый в настоящей работе набор пекинской капусты включал главным образом скороспелые образцы полукочанных сортотипов Шантунг (в том числе подтип Санто с исключительными салатными качествами), Сяо, кочанных с открытой вершиной Касин и Чосен, а также некоторые образцы типично кочанных сортотипов Чифу (подтип Мацусима из Японии), Кага, Дацинкоу, гибрид между типами Санто и Хэтоу, а также листового сортотипа Чиримен, несущего черты листовой репы (наличие короткого черешка и утолщенного корня). Образцы салатные, с компактной листовой 
розеткой, крупной листовой пластинкой (часто длиной более 40 см), плотной консистенции, без опушения или со слабым мягким опушением. Листья розетки направлены преимущественно косо вверх (30).

В исследовании были представлены все сортотипы китайской капусты, за исключением относительно позднеспелого Ютсай. Сорта сортотипа Тайсай имеют сомкнутую розетку направленных вверх листьев, с очень длинным (более 25 см) белым или бледно-зеленым черешком. К сортотипу Пиорбай с полураскидистой розеткой и относительно многочисленными листьями на черешках средней длины (15-20 см) относятся продуктивные образцы, часто устойчивые к альтернариозу и пероноспорозу, с плотной нежной консистенцией темно-зеленой листовой пластинки и светло-зеленого черешка.

Самые популярные образцы китайской капусты относятся к сортотипу Сыюсман. Это типичный пак-чой, с компактной листовой розеткой типа «ваза», часто растения устойчивы к загущению. Черешки относительно короткие (8-13 см), очень широкие (5-7 см), толстые, светло-зеленые. Заслуживают особого внимания образцы мини-пак-чой (беби-пак-чой), очень скороспелые (25-28 сут), с мелкой компактной розеткой (15-18 см).

Сортотип Лейчой представлен стабильными гибридами между образцами сортотипов Ютсай и Сыюсман, розеточной капустой и листовой репой. Им свойственны толстые ярко-белые черешки блестящих темно-зеленых выпуклых листьев, относительно высокая продуктивность (5-7 кг/м²), устойчивость к стеблеванию. У образцов близкого типа Джойчой листовая розетка мелкая (18-20 см), раскидистая и полураскидистая, листья слабо приподнятые, консистенция листьев очень плотная, хрустящая.

Для образцов розеточной капусты характерна компактная листовая розетка с направленными косо вверх (тип Хризантемум) и слабо приподнятыми многочисленными неясно-лировидными листьями (тип Тацай, плоская капуста, черная китайская капуста); черешки короткие и средней длины (6-13 см), узкие, зеленые, листовые пластинки глубокого темнозеленого цвета, блестящие, выпуклые, складчато-пузырчатые. Розеточная капуста включает сорта с листовой розеткой малых и очень малых размеров (12-18 см), декоративной, похожей на цветок. Образцы низкоурожайные, но имеют очень ценный биохимический состав: содержание аскорбиновой кислоты - 35-60 мг/100 г, хлорофиллов - 125-230 мг/100 г, $\beta$-каротина - 4-7 мг/100 г.

Образцы японской капусты типа Мизуна с сильно рассеченными листьями декоративные, с полураскидистой розеткой, устойчивы к стеблеванию. У образцов пурпурной капусты черешки листьев длинные (20-25 см), вверх и косо вверх направленные, пурпурные; характеризуются высоким содержанием биологически активных веществ при средней продуктивности.

У листовой репы листья крупные, направленные вверх, цельные и лировидно-рассеченные; черешки длинные (15-25 см) и средней длины, светло-зеленые. Образцы продуктивные, устойчивые к стеблеванию, используются после кулинарной обработки.

Таким образом, сформированный набор образцов капустных культур $B$. rapa обладал потенциальным разнообразием качественных характеристик и адаптивных реакций на условия среды, в том числе световые и температурные.

Основной лимитирующий фактор при выращивании капустных культур в зимний и ранневесенний периоды в теплицах - недостаточная 
освещенность. Показано (31), что при низкой освещенности адаптации растений проявляются в усиленном развитии светособирающего комплекса за счет увеличения ассимиляционной поверхности и количества фотосинтетических пигментов при более экономном расходовании ассимилятов на рост с уменьшением удельной поверхностной плотности (УПП) листьев, хотя у растений горчицы корнеплодной с сильно рассеченными листьями наблюдалось увеличение УПП. Например, растения репы Тохоку Хакусай выделялись повышенной теневыносливостью по сравнению с образцом горчицей корнеплодной к-18 (31). В условиях низкой освещенности у растений репы увеличивалась площадь листьев и повышалось содержание пигментов фотосинтеза (31).

Продолжительность светового периода (12-часовой день) и высокая освещенность в условиях биополигона препятствуют переходу длиннодневных растений вида в репродуктивную фазу онтогенеза. Большинство культур вида $B$. rapa холодостойкие, в центрах формирования разнообразия они часто выращиваются в осенний, зимний и ранневесенний периоды, обычно в плодородной почве при большой площади питания (особенно пекинская капуста). Чтобы выделить образцы со стабильным проявлением ценных признаков, связанных с продуктивностью, мы изучили морфофизиологические особенности генетического разнообразия отобранных образцов в условиях светоустановки при температуре выше биологических требований культур, в тонком слое почвенного субстрата и при разной мощности светового потока. Дополнительно учитывался тот факт, что при отсутствии отдельных помещений для каждой культуры температурный режим определяется требованиями культур с узкой нормой реакции, выращиваемых совместно с зеленными (в нашем исследовании томата и огурца).

Листья - основной фотосинтезирующий и продуктовый орган зеленных капустных культур. К важным признакам, характеризующим деятельность фотосинтетического аппарата растений, относится площадь листовой поверхности. Площадь листьев при изучении фотосинтетического аппарата определяют в современных условиях с помощью фотопланиметра или системы цифрового анализа изображений SIMAGIS $^{\circledR}$ MesoPlant $^{\mathrm{TM}}$ («Smart Imaging Technologies Co.», США). В то же время методы расчета площади листьев по легко измеряемым линейным размерам также сохраняют значение. Площадь листьев некоторых овощных культур может быть рассчитана с использованием уравнений регрессии по Н.Ф. Коняеву (32, 33). Молодые цельные листья пекинской капусты и листовой репы наиболее близки по форме к листьям рассады белокочанной капусты, а лировидно-рассеченные листья японской капусты - к листьям редиса, для которых Н.Ф. Коняевым предложены формулы расчета. В.В. Николенко и С.Ф. Котовым предложен способ вычисления площади листа земляники, Н.С. Киселевой - площади листа груши $(34,35)$. В доступной литературе мы не нашли расчетов площади листа как у китайской, розеточной и пурпурной капуст, так и у культур с близкой им формой листа. К тому же тип и форма листовой пластинки образцов одной культуры, прежде всего пекинской и китайской капусты, включающих большое разнообразие морфотипов, значительно различаются. Листья взрослого растения пекинской капусты преимущественно цельные сидячие, тогда как первые настоящие листья у большинства образцов цельные с черешком разной длины. Полученные нами расчетные коэффициенты для определения площади листьев у изученных образов различаются (табл. 2). Для расчетов по фотографии лист вписывали в прямоугольник, длина и ширина которого соответствует 
наибольшей длине и ширине листа растения (без учета черешка). Поправочный коэффициент для анализируемого листа представлял собой частное от деления площади листа в пикселях на площадь прямоугольника. Среднее для 5 листьев принимали за средний поправочный коэффициент для изучаемого растения, далее рассчитывали коэффициенты для каждого образца как среднее пяти растений в образце. Объединяя в группы образцы по типу листьев, нашли средние показатели для каждого типа листьев.

2. Поправочные коэффициенты, полученные для расчета площади листовой поверхности у образцов восточноазиатских капустных культур Brassica rapa L. из коллекции ВИР $(n=5$, биополигон ФГБНУ АФИ, г. Санкт-Петербург, 2019 год).

\begin{tabular}{|c|c|c|c|c|}
\hline \multirow{2}{*}{ Тип листа } & \multirow{2}{*}{ Форма листовой пластинки } & \multicolumn{3}{|c|}{ Коэффициенты } \\
\hline & & $\min$ & $\max$ & средний \\
\hline \multicolumn{5}{|c|}{ К а п ус т а п е к и нс к а я Brassica rapa L. subsp. pekinensis (Lour.) Hanelt } \\
\hline \multirow[t]{7}{*}{ Цельный } & Широколанцетовидная & 0,567 & 0,802 & $0,671 \pm 0,055$ \\
\hline & Удлиненно-обратнояйцевидная & 0,607 & 0,628 & $0,618 \pm 0,012$ \\
\hline & Обратнояйцевидная & 0,646 & 0,672 & $0,660 \pm 0,027$ \\
\hline & Овальная & 0,684 & 0,698 & $0,690 \pm 0,011$ \\
\hline & Широкоовальная & 0,717 & 0,748 & $0,729 \pm 0,031$ \\
\hline & Округлая & 0,778 & 0,802 & $0,790 \pm 0,035$ \\
\hline & \multicolumn{4}{|c|}{ К а п у с т а к и т а й с к а я Brassica rapa L. subsp. chinensis (L.) Hanelt } \\
\hline Лировидный & Усеченно-эллиптическая/овальная & 0,552 & 0,821 & $0,651 \pm 0,073$ \\
\hline Неясно лировидный & Усеченно-эллиптическая/овальная & 0,633 & 0,645 & $0,640 \pm 0,018$ \\
\hline \multirow[t]{4}{*}{ Цельный } & Яйцевидная & 0,660 & 0,682 & $0,672 \pm 0,230$ \\
\hline & Овальная & 0,690 & 0,719 & $0,703 \pm 0,238$ \\
\hline & Округлая & 0,733 & 0,794 & $0,765 \pm 0,042$ \\
\hline & Широкоокруглая & 0,805 & 0,821 & $0,818 \pm 0,016$ \\
\hline \multicolumn{5}{|c|}{ К а п у с т а роз е т о ч н а я Brassica rapa L. subsp. narinosa (Bailey) Hanelt } \\
\hline Неясно лировидный & Широкоовальная & 0,645 & 0,655 & $0,649 \pm 0,016$ \\
\hline \multicolumn{5}{|c|}{ К а п у с та я по н с к а я Brassica rapa $\mathrm{L}$. subsp. nipposinica (Bailey) Hanelt } \\
\hline Лировидный & Непарно перисто-рассеченная & 0,443 & 0,464 & $0,451 \pm 0,011$ \\
\hline \multicolumn{5}{|c|}{ К а п у с т а п у р п у р н а я Brassica rapa L. subsp. chinensis (L.) Hanelt var. pupuraria Kitam } \\
\hline Цельный & Овальная & 0,663 & 0,721 & $0,692 \pm 0,041$ \\
\hline \multicolumn{5}{|c|}{ Л и с т о в а я р е п а Brassica rapa L. subsp. rapifera Hook. var. komatsuna Makino } \\
\hline Цельный & Широкояйцевидная/широкоовальная & 0,791 & 0,814 & $0,801 \pm 0,028$ \\
\hline
\end{tabular}

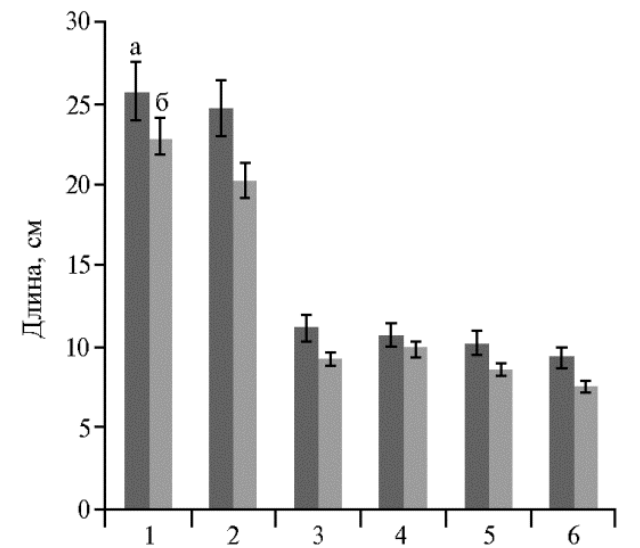

Сообщалось (31), что пониженная освещенность вызывает формирование большей площади листовой поверхности у репы и горчицы. В наших исследованиях размеры листовой розетки, число листьев и линейные размеры листовой пластинки капустных культур в зависимости от освещенности в среднем различались на 9-25 \% (табл. 3, рис. 1) и были во всех случаях больше при повышенной освещенности. Этот вывод согласуется с результатами изучения салата посевного Lactuca sativa L. (35-37), капусты розеточной (38) и капусты пурпурной (39) при различных уровнях облученности.
Рис. 1. Длина листовой пластинки у образцов восточноазиатских капустных культур Brassica rapa L. из коллекции ВИР в интенсивной светокультуре в зависимости от освещенности: 1 пекинская капуста Brassica rapa L. subsp. pekinensis (Lour.) Hanelt, 2 - репа листовая Brassica rapa L. subsp. rapifera Hook. var. komatsuna Makino, 3 - китайская капуста Brassica rapa L. subsp. chinensis (L.) Hanelt, 4 японская капуста Brassica rapa L. subsp. nipposinica (Bailey) Hanelt, 5 - пурпурная капуста Brassica rapa L. subsp. chinensis (L.) Hanelt var. pupuraria Kitam, 6 - розеточная капуста Brassica rapa L. subsp. narinosa (Bailey) Hanelt; a высокая освещенность (15-20 клк), б - низкая освещенность (10-15 клк) ( $n=5, M \pm \mathrm{SEM}$; биополигон ФГБНУ АФИ, г. Санкт-Петербург, 2019 год). 
3. Морфологические признаки и урожайность у образцов восточноазиатских капустных культур Brassica rapa L. из коллекции ВИР в интенсивной светокультуре в зависимости от освещенности $(n=5, M \pm \mathrm{SEM}$; биополигон ФГБНУ АФИ, г. Санкт-Петербург, 2019 год)

\begin{tabular}{|c|c|c|c|c|c|c|c|c|}
\hline \multirow{2}{*}{ Освещенность } & \multicolumn{2}{|c|}{ Размеры розетки, см } & \multirow{2}{*}{$\begin{array}{l}\text { Число ли- } \\
\text { стьев, шт. }\end{array}$} & \multicolumn{2}{|c|}{ Размеры листовой пластинки, см } & \multirow{2}{*}{$\begin{array}{l}\text { Площадь одной листовой пластинки/ } \\
\text { листовой поверхности растения, см}{ }^{2}\end{array}$} & \multirow{2}{*}{$\begin{array}{l}\text { Масса } \\
\text { растения, г }\end{array}$} & \multirow{2}{*}{$\begin{array}{l}\text { Урожайность, } \\
\text { кг/м² }\end{array}$} \\
\hline & высота & диаметр & & длина & ширина & & & \\
\hline \multirow{3}{*}{$\begin{array}{l}\text { Высокая (15-20 клк) } \\
\text { Cv, \% }\end{array}$} & & К а пуста & пе к и н с к ая & я Brassica rapa & subsp. Pekinensis Brassica & rapa L. subsp. pekinensis (Lour.) Hanelt (36 обра & $\mathrm{IOB})$ & \\
\hline & $26,60 \pm 0,83$ & $26,50 \pm 0,71$ & $8,60 \pm 0,24$ & $25,70 \pm 0,80$ & $11,90 \pm 0,37$ & $204,91 / 1762,23$ & $50,40 \pm 3,49$ & $6,30 \pm 0,32$ \\
\hline & 19,56 & 16,65 & 17,44 & 19,37 & 19,61 & & 43,26 & \\
\hline \multirow{2}{*}{$\begin{array}{l}\text { Низкая (10-15 клк) } \\
\quad C v, \%\end{array}$} & $23,80 \pm 0,65$ & $24,20 \pm 0,56$ & $8,20 \pm 0,21$ & $22,90 \pm 0,67$ & $10,40 \pm 0,30$ & $159,57 / 1308,47$ & $33,90 \pm 2,25$ & $4,24 \pm 0,23$ \\
\hline & 16,49 & 13,97 & $\begin{array}{l}15,55 \\
\mathrm{~K} \text { а п у с т }\end{array}$ & $\begin{array}{cc} & 17,55 \\
\text { a } & \text { к и т а й с к }\end{array}$ & $\begin{array}{cc} & 17,44 \\
\text { а я } & \text { Brassica rapa } \text { L. subs }\end{array}$ & chinensis (L.) Hanelt (23 образца) & 39,79 & \\
\hline \multirow{3}{*}{$\begin{array}{l}\text { Высокая }(15-20 \text { клк) } \\
C v, \% \\
\text { Низкая (10-15 клк) } \\
\quad C v, \%\end{array}$} & $\begin{array}{c}23,30 \pm 0,94 \\
19,78\end{array}$ & $\begin{array}{l}19,80 \pm 1,14 \\
28,26\end{array}$ & $\begin{array}{c}8,30 \pm 0,29 \\
17,08\end{array}$ & $\begin{array}{l}11,20 \pm 0,58 \\
25,26\end{array}$ & $\begin{array}{l}8,80 \pm 0,40 \\
22,21\end{array}$ & $73,92 / 613,54$ & $\begin{array}{l}41,50 \pm 4,01 \\
\quad 48,33\end{array}$ & $5,19 \pm 0,37-8,30 \pm 0,57^{a}$ \\
\hline & $19,90 \pm 1,13$ & $15,80 \pm 1,04$ & $7,90 \pm 0,33$ & $9,20 \pm 0,60$ & $7,30 \pm 0,44$ & $50,37 / 397,92$ & $30,10 \pm 3,59$ & $3,76 \pm 0,31-6,02 \pm 0,48^{a}$ \\
\hline & 27,32 & 31,68 & $\begin{array}{c}20,42 \\
\text { Ка пуст а }\end{array}$ & $\begin{array}{c}31,29 \\
\text { роз ет очн }\end{array}$ & $\begin{array}{c}29,11 \\
\text { a Я Brassica rapa L. subsp }\end{array}$ & zarinosa (Bailey) Hanelt (3 образца) & 57,38 & \\
\hline \multirow{3}{*}{$\begin{array}{l}\text { Высокая (15-20 клк) } \\
C v, \% \\
\text { Низкая (10-15 клк) } \\
\quad C v, \%\end{array}$} & $\begin{array}{l}22,00 \pm 1,55 \\
15,76\end{array}$ & $\begin{array}{l}20,70 \pm 2,02 \\
21,81\end{array}$ & $\begin{array}{c}15,40 \pm 6,21 \\
69,73\end{array}$ & $\begin{array}{l}9,40 \pm 1,33 \\
31,71\end{array}$ & $\begin{array}{l}7,20 \pm 0,88 \\
27,34\end{array}$ & $43,99 / 677,45$ & $\begin{array}{l}33,60 \pm 3,30 \\
21,96\end{array}$ & $4,20 \pm 0,28-6,72 \pm 0,49^{a}$ \\
\hline & $17,90 \pm 1,16$ & $17,50 \pm 2,9$ & $13,60 \pm 2,91$ & $7,50 \pm 1,15$ & $6,50 \pm 0,94$ & $31,69 / 430,98$ & $25,90 \pm 8,27$ & $3,24 \pm 0,49-5,18 \pm 0,78^{a}$ \\
\hline & 11,21 & 28,68 & $\begin{array}{c}47,86 \\
\text { К а п у с т а }\end{array}$ & $\begin{array}{c}26,36 \\
\text { я п о н с к а }\end{array}$ & $\begin{array}{c}25,14 \\
\text { Brassica rapa } \text { L. subsp. } n\end{array}$ & ipposinica (Bailey) Hanelt (3 образца) & 55,36 & \\
\hline \multirow{3}{*}{$\begin{array}{l}\text { Высокая (15-20 клк) } \\
C v, \% \\
\text { Низкая (10-15 клк) } \\
\quad C v, \%\end{array}$} & $\begin{array}{l}23,60 \pm 1,91 \\
14,00\end{array}$ & $\begin{array}{l}19,10 \pm 0,93 \\
8,45\end{array}$ & $\begin{array}{l}13,70 \pm 4,12 \\
52,03\end{array}$ & $\begin{array}{l}10,70 \pm 0,45 \\
7,30\end{array}$ & $\begin{array}{l}7,10 \pm 0,29 \\
7,06\end{array}$ & $34,19 / 468,40$ & $\begin{array}{c}22,70 \pm 1,97 \\
15,00\end{array}$ & $2,84 \pm 0,22$ \\
\hline & $\begin{array}{c}20,80 \pm 0,20 \\
1,67\end{array}$ & $\begin{array}{c}17,20 \pm 1,25 \\
12,58\end{array}$ & $\begin{array}{c}12,10 \pm 3,23 \\
46,16\end{array}$ & $\begin{array}{l}9,80 \pm 0,91 \\
16,09\end{array}$ & $\begin{array}{c}7,10 \pm 0,74 \\
18,20\end{array}$ & $31,31 / 378,85$ & $\begin{array}{c}17,80 \pm 1,39 \\
13,49\end{array}$ & 2,23 \\
\hline & & $\mathrm{K}$ а п & густ а пурп & п урн а я Bras. & ica rapa L. subsp. chinensi & s (L.) Hanelt var. pupuraria Kitam (2 образца) & & \\
\hline \multirow{4}{*}{$\begin{array}{l}\text { Высокая (15-20 клк) } \\
\quad C v, \% \\
\text { Низкая (10-15 клк) } \\
\quad C v, \%\end{array}$} & $\begin{array}{l}23,10 \pm 1,30 \\
7,96\end{array}$ & $\begin{array}{l}22,40 \pm 3,00 \\
18,94\end{array}$ & $\begin{array}{l}5,70 \pm 0,30 \\
7,44\end{array}$ & $\begin{array}{c}10,30 \pm 1,45 \\
20,01\end{array}$ & $\begin{array}{l}8,50 \pm 1,25 \\
20,92\end{array}$ & $60,58 / 345,31$ & $\begin{array}{l}19,50 \pm 0,50 \\
\quad 3,59\end{array}$ & $2,44 \pm 0,06-3,90 \pm 0,08^{a}$ \\
\hline & $21,50 \pm 1,10$ & $19,00 \pm 0,40$ & $5,30 \pm 0,10$ & $8,60 \pm 0,25$ & $7,40 \pm 0,60$ & $44,04 / 233,41$ & $14,60 \pm 3,93$ & $1,83 \pm 0,27-2,92 \pm 0,44 \mathrm{a}$ \\
\hline & 7,24 & 2,98 & 2,67 & 4,14 & 11,47 & & 37,99 & \\
\hline & & & Лисстов а я 1 & ре п а Brassice & rapa L. subsp. rapifera $\mathrm{H}$ & ook. var. komatsuna Makino (5 образцов) & & \\
\hline $\begin{array}{l}\text { Высокая (15-20 клк) } \\
\quad C v, \%\end{array}$ & $\begin{array}{l}29,00 \pm 3,16 \\
24,41\end{array}$ & $\begin{array}{l}29,90 \pm 5,19 \\
34,80\end{array}$ & $\begin{array}{l}8,30 \pm 0,78 \\
21,03\end{array}$ & $\begin{array}{l}24,70 \pm 3,65 \\
\quad 33,07\end{array}$ & $\begin{array}{l}12,60 \pm 1,54 \\
27,35\end{array}$ & $248,98 / 2066,53$ & $\begin{array}{l}63,80 \pm 14,40 \\
50,47\end{array}$ & $7,98 \pm 1,11-12,76 \pm 1,91^{\mathrm{a}}$ \\
\hline Низкая (10-15 клк) & $24,40 \pm 2,47$ & $27,20 \pm 3,16$ & $7,60 \pm 0,64$ & $20,30 \pm 2,93$ & $10,50 \pm 1,21$ & $170,52 / 1295,95$ & $33,70 \pm 7,37$ & $4,21 \pm 0,63-6,74 \pm 01,01^{\mathrm{a}}$ \\
\hline$C v, \%$ & 22,64 & 26,01 & 18,82 & 32,28 & 25,84 & & 48,88 & \\
\hline Среднее & $23,00 \pm 0,62$ & $21,60 \pm 1,07$ & $9,60 \pm 0,80$ & $14,20 \pm 1,77$ & $8,80 \pm 0,50$ & $96,20 \pm 19,23 / 831,60 \pm 149,65$ & $32,30 \pm 3,04$ & \\
\hline $\mathrm{HCP}_{05}$ & 1,85 & 3,20 & 2,39 & 5,32 & 1,49 & $57,69 / 448,96$ & 9,13 & \\
\hline
\end{tabular}


Достоверные различия отмечены для признаков высота розетки у всех культур (за исключением пурпурной капусты), ширина пластинки, масса растения и урожайность у пекинской, китайкой капусты и листовой репы, площади листовой поверхности у листовой репы.

По всей вероятности, это объясняется площадью питания растений, близкой к оптимальной при данных условиях выращивания, позволившей растениям избегать взаимного затенения, и наличием относительно большого количества теневыносливых генотипов, а также оптимальным режимом минерального питания. В то же время площадь листовой поверхности у одного растения между культурами различалась в зависимости от освещенности уже на 24-59 \%, при этом наименьшую разницу между площадью листовой поверхности при неодинаковой освещенности отмечали у японской капусты, наибольшую - у листовой репы, китайской и розеточной капусты.

Коэффициенты вариации морфологических признаков каждой культуры независимо от освещенности были средние и не превышали $20 \%$ у образцов пекинской и пурпурной капусты, а также у розеточной и японской капусты (у двух последних культур - за исключением высоко варьирующего числа листьев), то есть по силе роста (размерам) растений исследованные образцы капустных культур были близки. Образцы китайской капусты и листовой репы различались между собой значительно с коэффициентами вариации до 32 \% у китайской капусты, до $35 \%-$ у листовой репы.

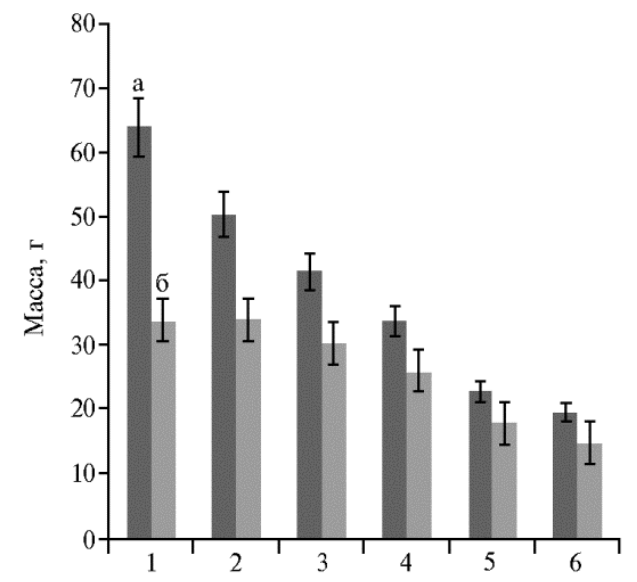

Рис. 2. Масса растения у образцов восточноазиатских капустных культур Brassica rapa L. из коллекции ВИР в интенсивной светокультуре в зависимости от освещенности: 1 - репа листовая Brassica rapa L. subsp. rapifera Hook. var. komatsuna Makino, 2 - пекинская капуста Brassica rapa L. subsp. pekinensis (Lour.) Hanelt, 3 китайская капуста Brassica rapa L. subsp. chinensis (L.) Hanelt, $4-$ розеточная капуста Brassica rapa L. subsp. narinosa (Bailey) Hanelt, 5 - японская капуста Brassica rapa L. subsp. nipposinica (Bailey) Hanelt, 6 - пурпурная капуста Brassica rapa L. subsp. chinensis (L.) Hanelt var. pupuraria Kitam; а - высокая освещенность (15-20 клк), б - низкая освещенность (10-15 клк) $(n=5, M \pm \mathrm{SEM}$; биополигон ФГБНУ АФИ, г. Санкт-Петербург, 2019 год).

Различия по массе растения и, соответственно, урожайности в зависимости от освещенности были существенными (больше $\mathrm{HCP}_{05}$ 9,13 г) и особенно значительными у листовой репы и пекинской капусты, в менышей степени у китайской капусты; превышение массы растения розеточной, пурпурной, японской капусты при высоком уровне освещенности было недостоверным (см. табл. 3, рис. 2). Изменчивость массы растения была очень сильной между образцами пекинской и китайской капусты и листовой репы (коэффициенты вариации признака 40-57 \%).

Относительно низкую урожайность (более чем в 2 раза ниже урожайности пекинской капусты и листовой репы) отмечали у японской и пурпурной капусты, но декоративность и ценный биохимический состав, особенно высокое содержание хлорофиллов, каротинов, антоциана (7) делают их также перспективными для выращивания в светокультуре.

Все изученные количественные признаки (размеры и масса растений) коррелируют между собой в высокой степени (коэффициенты 
корреляции $r=0,72-0,98 ; \mathrm{p} \leq 0,05)$, в том числе средняя площадь листовой поверхности и масса растения изученного набора образцов связаны сильной корреляцией $(r=0,88 ; \mathrm{p} \leq 0,05)$. Число листьев связано слабой и средней по силе обратной корреляционной зависимостью ( $r$ от $-0,11$ до $-0,38 ; \mathrm{p} \leq 0,05)$ со всеми показателями размеров розетки и листьев и не коррелирует с массой растения.

Среди изученных образцов капустных культур мы выявили источники для селекции на скороспелость, продуктивность и устойчивость к раннему стеблеванию и краевому ожогу. Так, 44 \% образцов пекинской капусты из изученного набора при высокой освещенности имели массу растения выше средней по выборке (урожайность выше 6,3 кг $/ \mathrm{M}^{2}$ ), в том числе 9 образцов преимущественно салатных сортотипов Шантунг, Санто, Сяо имели урожайность более 7,5 кг/м², то есть на 22-109 \% выше средней по культуре в выборке. Все эти образцы формировали высокий урожай за 28 сут, то есть проявляли скороспелость. Самую высокую массу растения среди образцов пекинской капусты отмечали у линии, выделенной из японского гибрида полукочанного сортотипа Шантунг Shantung Tropical Round F1 (к-406) $(105,40 \pm 17,50$ г) и у местных китайских образцов сортотипа Сяо к-185

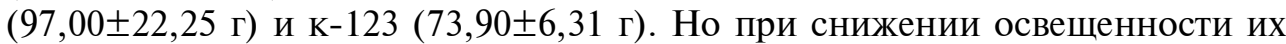
продуктивность падала на 46-125 \%, что указывает на их высокую требовательность к уровню освещенности (табл. 4).

4. Изменчивость показателей продуктивности у выделившихся образцов восточноазиатских капустных культур Brassica rapa L. из коллекции ВИР в интенсивной светокультуре в зависимости от освещенности ( $n=5, M \pm \mathrm{SEM}$; биополигон ФГБНУ АФИ, г. Санкт-Петербург, 2019 год)

\begin{tabular}{|c|c|c|c|c|c|c|c|}
\hline \multirow{2}{*}{$\begin{array}{l}\text { Номер по } \\
\text { каталогу }\end{array}$} & \multirow[t]{2}{*}{ Название образца } & \multicolumn{2}{|c|}{$\begin{array}{l}\text { Площадь листовой } \\
\text { поверхности, см }{ }^{2}\end{array}$} & \multicolumn{2}{|c|}{ Масса растения, г } & \multicolumn{2}{|c|}{ Урожайность, кг/м² } \\
\hline & & высокая & низкая & высокая & низкая & высокая & низкая \\
\hline \multicolumn{8}{|c|}{ К а п у с т а п е к и н с к а я Brassica rapa subsp. Pekinensis Brassica rapa L. subsp. pekinensis (Lour.) Hanelt } \\
\hline $\mathrm{K}-406$ & Shantung Tropical Round & & & & & & \\
\hline K-185 & Местный & 3191,37 & 2682,94 & $97,00 \pm 22,25$ & $55,50 \pm 8,72$ & $12,13 \pm 1,98$ & $\begin{array}{l}5,0 J \pm 0,4 J \\
6,94 \pm 0,70\end{array}$ \\
\hline-270 & Harumaki Shin Santousai & 3143,61 & 3473,24 & $86,40 \pm 6,97$ & $71,70 \pm 5,98$ & 10 , & 54 \\
\hline $\mathrm{K}-629$ & Yoko $F_{1}$ & 2368,28 & 1952,48 & $82,40 \pm 7,23$ & $68,20 \pm 3,48$ & $1 \pm 0,72$ & $2 \pm 0,34$ \\
\hline вр.к-1120 & Zao Shi № 5 & 127. & 934,61 & 7,50 & $58,60 \pm 1,85$ & 9, &, 22 \\
\hline $\mathrm{k}-123$ & Сяобайкоу & 190 & 41 & 73, & 50, & 9,2 & 25 \\
\hline вр.к-1410 & Fun jen $F_{1}$ & 2191,75 & 1446,71 & $71,50 \pm 5,46$ & $47,70 \pm 1,27$ & $8,93 \pm 0,63$ & $5,97 \pm 0,16$ \\
\hline вр.к-1376 & Бице & 2050,61 & 1602,77 & 68,6 & $48,50 \pm 2,50$ & $8,57 \pm 0,86$ & $6,06 \pm 0,24$ \\
\hline $\mathrm{K}-395$ & Tokyo Bekana & 2006 & 1557,81 & 65,9 & 10,33 & 49 & 1,01 \\
\hline K-74 & Сяоб & 193 & 1636,79 & 65, & 5,80 & 37 &, 56 \\
\hline \multirow[t]{2}{*}{$\mathrm{K}-457$} & Осенняя 2 & 2158,34 & 2081,80 & $59,50 \pm 6,08$ & $53,40 \pm 4,58$ & $7,44 \pm$ & 6 , \\
\hline & уста к & а й с к а я & Brassica $r$ & apa L. subsp. c & chinensis (L.) l & Hanelt & \\
\hline $\mathrm{K}-116$ & Taisai & 1087,59 & 901,55 & $82,80 \pm 17,10$ & $65,10 \pm 12,15$ & $12,85 \pm 2,31$ & $8,14 \pm 1,38$ \\
\hline вр.к-1128 & Hanging & 899,90 & 742,28 & $77,20 \pm 13,25$ & $57,90 \pm 7,91$ & $5 \pm 1,54$ & $7,24 \pm 0,80$ \\
\hline вр.к-1131 & Kangre 605 & & 79 & 67,2 & 82 & 92 & 0,48 \\
\hline вр.к-1124 & Gai Lang Jin & & 57 & 54, & 51 & & 8 \\
\hline вр.к-932 & Pack Choi & 606 & 494,74 & 50,5 & 42 , & 82 & 3 \\
\hline \multirow[t]{2}{*}{ вр.к-1405 } & Extra dwarf PC & 415,81 & 324,56 & $44,70 \pm 5,94$ & $42,30 \pm 6,39$ & $8,95 \pm 0,90$ & $8,46 \pm 1,02$ \\
\hline & $03 \mathrm{e}$ & точн н я & Brassica ral & $p a$ L. subsp. $r$ & arinosa (Bailey & y) Hanelt & \\
\hline K-695 & Xiao Ba Je Ta Cai & 613,86 & 544,99 & $40,10 \pm 4,38$ & $39,70 \pm 5,17$ & $8,01 \pm 0,64$ & 7,9 \\
\hline \multirow[t]{2}{*}{ вр.к-1398 } & Yukina Savoy & 721,59 & 539,01 & $32,30 \pm 2,37$ & $26,10 \pm 3,30$ & $6,45 \pm 0,38$ & $5,23 \pm 0,53$ \\
\hline & в ая репа & Brassica & pa L. subsp. & rapifera Hook & k. var. komatsl & una Makino & \\
\hline вр.к- 1418 & Komatsuna & 3720,04 & 2966,65 & $102,20 \pm 11,10$ & $61,50 \pm 17,27$ & $12,78 \pm 1,28$ & $7,69 \pm 1,69$ \\
\hline $\mathrm{K}-335$ & Hiroshimana & 3307,82 & 1084,51 & $90,30 \pm 9,50$ & $30,00 \pm 4,18$ & $11,29 \pm 0,91$ & $3,75 \pm 0,43$ \\
\hline вр.к-1372 & Бирюза & 2533,19 & 1755,17 & $75,00 \pm 4,16$ & $52,70 \pm 2,15$ & $9,38 \pm 0,37$ & $6,59 \pm 0,20$ \\
\hline вр.к-1371 & Селекта & 1263,09 & 896,37 & $68,70 \pm 7,88$ & $46,40 \pm 2,94$ & $8,59 \pm 0,86$ & $5,80 \pm 0,35$ \\
\hline
\end{tabular}

Также высокой массой растения выделялись старинные японские сорта сортотипа Санто Harumaki Shin Santousai (к-270) $(86,40 \pm 6,97$ г) и

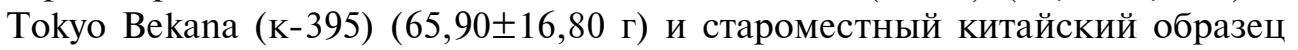


сортотипа Сяо Сяобайкоу (к-74) $(65,70 \pm 4,11$ г), при этом морфологические показатели растений, включая их массу, при снижении освещенности уменьшались не более чем на 5-20 \%, и самую высокую стабильность признаков при разной освещенности показал образец Tokyo Bekana (различия между показателями массы растения при высокой и низкой освещенности в 3 раза ниже $\left.\mathrm{HCP}_{05}\right)$.

Остальные образцы пекинской капусты характеризовались урожайностью менее 6,3 кг/м² и пониженной скоростью роста. Несмотря на устойчивость большинства из них к низкой освещенности, они не рекомендуются для интенсивной светокультуры, хотя могут быть включены в селекционные программы в качестве источников адаптивности - как, например, корейский сорт с высокими показателями качества листьев Осенняя 2 (к-457) сортотипа Чосен.

Три образца китайской капусты при высокой освещенности имели массу растения более 60 г: это староместный японский образец длинночерешкового сортотипа Таisai (к-116) $(82,80 \pm 17,10$ г) и современные китайские сорта сортотипа Сыюсман с сомкнутой компактной розеткой Hanging (вр.к-1128) и Kangre 605 (вр.к-1131) (соответственно

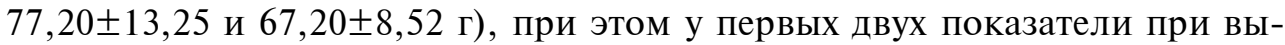
сокой освещенности были выше на 27-33 \%, а у последнего практически не зависели от уровня освещенности.

У представителей сортотипов Пиорбай, Сыюсман, Джойчой и Лейчой четырех современных сортов китайской капусты из Китая, Японии и США масса растения находилась в пределах 50-60 г, еще у четырех образцов из Китая, США и Киргизии - 40-50 г. Практически не реагировали на изменение освещенности образцы китайской капусты высокоурожайный Gai Lang Jin Pin 25 F1 (вр.к-1124) и Pack Choi F1 (вр.к-932) со средней урожайностью. Образцы китайской капусты с урожайностью ниже 5 кг/м $\mathrm{M}^{2}$ не рекомендуются для выращивания в светокультуре.

Среди изученных образцов со стабильно высокой продуктивностью выделились образцы с суперкомпактной розеткой - китайской капусты Ехtra Dwarf Pack Choi (вр.к-1405) (8,46-8,95 кг/м²) и розеточной капусты Хiao Ba Je Ta Cai (к-695) (7,94-8,01 кг/м²), пригодные для загущенного выращивания при схеме посадки $10 \times 5$ см. Образцы низкорослые, их можно выращивать при расстоянии между стеллажами не более $30 \mathrm{~cm}$, если в качестве источников света использовать современные светодиодные светильники с высоким КПД, которые выделяют значительно меньше тепловой энергии, чем у лампы ДНа3-400. Для загущенного выращивания также представляет интерес образец розеточной капусты Yukina Savoy (вр.к-1398) (урожайность 5,20-6,40 кг/м²) с относительно стабильной продуктивностью и очень ценным биохимическим составом.

Изученные образцы японской капусты за 28 сут не смогли сформировать массу растения выше 25 г, при этом у двух сортов превышение массы растения при высокой освещенности составило 36-66 \%; у сорта японской капусты с красно-фиолетовыми листьями (вр.к-1360) показатели продуктивности были самые низкие $\left(2,05-3,80\right.$ кг $/ \mathrm{M}^{2}$ в зависимости от уровня освещенности). При загущенном выращивании урожайность японской капусты при высокой освещенности составила 3,80-5,10 кг/м ${ }^{2}$, наибольшей $\left(5,10 \pm 0,48\right.$ кг $\left./ \mathrm{M}^{2}\right)$ она была у японского сорта Shirojuki Sensujo Kyo Mizuna Nakate (к-463).

Образцы пурпурной капусты из Нидерландов также требуют более 
длительного выращивания: за 28 сут масса растения у них составила 19-20 г, причем у образца вр.к-1357 она практически не зависела от освещенности.

Четыре образца листовой репы форм комацуна и хирошимана показали хорошую продуктивность. При высокой освещенности у образца

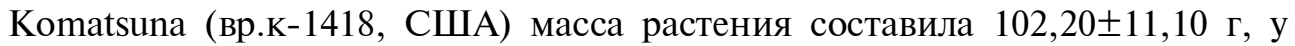

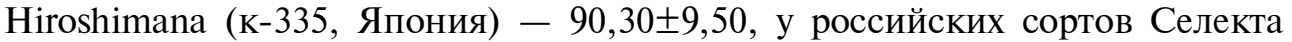
(вр.к-1371) и Бирюза (вр.к-1372) - 68,70-75,00 г, то есть урожайность достигала 8,59-12,78 кг/м². Однако при низкой освещенности показатели продуктивности всех образцов листовой репы падали на 43-81 \%.

Некоторые из изученных образцов формировали высокую массу растения при малой площади листовой поверхности, например китайский образец пекинской капусты Zao Shi № 5 (вр.к-1120), российский сорт листовой репы Селекта (вр.к-1371), что указывает на интенсивную работу их фотосинтетического аппарата.

Образцы капустных культур преимущественно были устойчивы к раннему стеблеванию, хотя до $10 \%$ растений перешли в фазу стеблевания у трех образцов пекинской капусты, двух - китайской капусты и одного образца листовой репы (все образцы южнокитайского и японского происхождения).

У пекинской капусты сортотипа Касин (кочанный с открытой вершиной) и трех образцов сортотипов Шантунг и Сяо наблюдали начало краевого ожога - физиологического нарушения, вызванного дефицитом кальция (отмечается главным образом у пекинской кочанной капусты, быстро развивается при повышенной температуре и влажности воздуха).

Наиболее высокое салатное качество листьев регистрировали у образцов пекинской капусты Chokurei (к-177), Tokyo Bekana (к-395), Zao Shi № 5 (вр.к-1120), Fun jen F1 (вр.к-1410). По качеству также представляют интерес образцы вр.к-1375 и Бице (вр.к-1376) из Киргизии с прямостоячей розеткой вверх направленных листьев, а также образец китайской капусты к-647 с зеленым черешком из Таджикистана.

5. Изменчивость размеров и массы растения у образцов китайской и розеточной капусты Brassica rapa L. из коллекции ВИР при разных условиях выращивания $(n=5, M \pm \mathrm{SEM}$; биополигон ФГБНУ АФИ, г. Санкт-Петербург, зимняя остекленная теплица и опытное поле Пушкинских лабораторий ВИР, Ленинградская обл., 2019 год)

\begin{tabular}{|c|c|c|c|c|c|c|}
\hline \multirow{3}{*}{ Условия выращивания } & \multicolumn{4}{|c|}{ Размеры, см } & \multirow{3}{*}{$\begin{array}{l}\text { Масса } \\
\text { растения, г }\end{array}$} & \multirow{3}{*}{$\begin{array}{l}\text { Урожай- } \\
\text { ность, кг/м² }\end{array}$} \\
\hline & \multicolumn{2}{|c|}{ листовой розетки } & \multicolumn{2}{|c|}{ листовой пластинки } & & \\
\hline & диаметр & высота & длина & ширина & & \\
\hline & & бразец & ai Lang Jin Pi & n 25 & & \\
\hline \multicolumn{7}{|l|}{ Биополигон: } \\
\hline $\begin{array}{l}\text { высокая освещенность } \\
\text { (15-20 клк) } \\
\text { низкая освешенность }\end{array}$ & $24,40 \pm 0,92$ & $16,20 \pm 0,8$ & $11,10 \pm 0,55$ & $8,20 \pm 0,49$ & $54,76 \pm 5,88$ & $5,48 \pm 0,49$ \\
\hline (10-15 клк) & $22,00 \pm 1,89$ & $15,00 \pm 0,95$ & $10,40 \pm 0,51$ & $7,60 \pm 0,51$ & $55,28 \pm 6,83$ & $5,53 \pm 0,61$ \\
\hline Теплица & $24,30 \pm 1,38$ & $15,30 \pm 0,91$ & $10,10 \pm 0,74$ & $7,30 \pm 0,62$ & $52,20 \pm 6,43$ & $5,22 \pm 0,57$ \\
\hline Поле & $22,10 \pm 1,47$ & $14,80 \pm 0,83$ & $9,70 \pm 0,73$ & $7,00 \pm 0,65$ & $50,60 \pm 6,21$ & $5,06 \pm 0,53$ \\
\hline \multicolumn{6}{|c|}{ О б р а з е ц Kangre 605} & 3,91 \\
\hline Биополигон: & & & & & & \\
\hline $\begin{array}{l}\text { высокая освещенность } \\
\text { (15-20 клк) } \\
\text { низкая освещенность }\end{array}$ & $26,20 \pm 1,74$ & $20,40 \pm 1,12$ & $12,60 \pm 0,74$ & $9,60 \pm 0,58$ & $65,22 \pm 4,78$ & $6,52 \pm 0,38$ \\
\hline (10-15 клк) & $25,80 \pm 0,86$ & $22,00 \pm 1,86$ & $13,80 \pm 0,97$ & $10,20 \pm 0,38$ & $66,88 \pm 7,94$ & $6,69 \pm 0,72$ \\
\hline Теплица & $24,30 \pm 1,28$ & $21,40 \pm 1,33$ & $13,00 \pm 1,12$ & $9,20 \pm 0,35$ & $61,40 \pm 5,15$ & $6,14 \pm 0,46$ \\
\hline Поле & $23,70 \pm 0,92$ & $20,60 \pm 1,75$ & $12,50 \pm 0,87$ & $9,10 \pm 0,43$ & $60,20 \pm 4,83$ & $6,02 \pm 0,42$ \\
\hline$C v, \%$ & 5,28 & 4,47 & 3,90 & 3,82 & 4,95 & 5,04 \\
\hline
\end{tabular}


Биополигон:

высокая освещенность

(15-20 клк)

низкая освещенность

(10-15 клк)

Теплица

Поле

Cv, \%

Биополигон:

высокая освещенность

(15-20 клк)

низкая освещенность (10-15 клк)

Теплица

Поле

$\mathrm{Cv}, \%$

O б p а з е ц Extra dwarf Pack Choi

$\begin{array}{cccccc}18,60 \pm 0,74 & 10,00 \pm 0,54 & 7,30 \pm 0,58 & 8,90 \pm 1,32 & 42,30 \pm 6,39 & 8,46 \pm 1,02 \\ 18,40 \pm 0,86 & 9,00 \pm 0,32 & 6,50 \pm 0,71 & 8,30 \pm 0,70 & 44,70 \pm 5,94 & 8,95 \pm 0,78 \\ 17,40 \pm 0,92 & 10,80 \pm 0,45 & 7,20 \pm 0,47 & 7,80 \pm 0,82 & 41,10 \pm 5,11 & 8,22 \pm 0,83 \\ 17,00 \pm 1,14 & 9,10 \pm 0,28 & 6,60 \pm 0,52 & 7,40 \pm 0,57 & 40,80 \pm 5,43 & 8,16 \pm 1,06 \\ 5,31 & 4,82 & 6,45 & 5,38 & 6,07 & 6,24\end{array}$

$20,80 \pm 1,31 \quad 13,40 \pm 0,59 \quad 6,40 \pm 0,69 \quad 5,90 \pm 0,29 \quad 39,70 \pm 5,17 \quad 7,94 \pm 0,80$

$19,40 \pm 0,94 \quad 13,60 \pm 0,51 \quad 5,80 \pm 0,20 \quad 5,20 \pm 0,30 \quad 40,10 \pm 4,38 \quad 8,01 \pm 0,64$

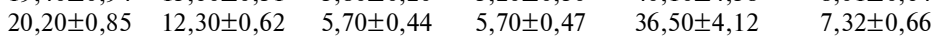

$20,90 \pm 0,12 \quad 13,36 \pm 0,93 \quad 6,40 \pm 0,54 \quad 5,40 \pm 0,38 \quad 35,60 \pm 3,61 \quad 7,11 \pm 0,57$ $\begin{array}{llllll}3,25 & 4,14 & 5,26 & 3,38 & 5,66 & 5,79\end{array}$

В изученной выборке среди образцов китайской и розеточной капусты мы выявили высокостабильные, сохраняющие морфологические и фенологические показатели в контрастных условиях открытого грунта, теплиц и агробиополигона, с очень малой изменчивостью признаков, которая определяется в основном генотипом. Это некоторые современные сорта, в том числе, по всей вероятности, несущие гены карликовости $d w f$ (40) (табл. 5). Выделившиеся формы, по нашему мнению, следует включить в селекционный процесс.

Таким образом, в результате исследований установлено, что повышение продуктивности растений всех капустных культур вида Brassica rapa в значительной мере определяется, как правило, интенсивностью светового потока. Для условий интенсивной светокультуры выделены наиболее высокоурожайные (более 6,3 кг/м²) образцы пекинской капусты и листовой репы, а также некоторые образцы китайской капусты. Изученные образцы пурпурной и японской капусты низкоурожайные и имеют более длительный вегетационный период, но представляют интерес в качестве овощей для функционального питания и для декоративных целей. Выявлены сортотипы пекинской капусты (Шантунг, Санто, Сяо), представляющие преимущественный интерес для светокультуры. В условиях биополигона мы выделили образцы с комплексом ценных признаков для различных направлений селекции. Так, проявили стабильную скороспелость и высокую продуктивность практически независимо от освещенности образцы пекинской капусты Harumaki Shin Santousai (к-270), Tokyo Bekana (к-395), Сяобайкоу (к-74), китайской капусты Kangre 605 (вр.к1131), Gai Lang Jin Pin 25 F1 (вр.к-1124). Показано, что у китайского образца пекинской капусты Zao Shi № 5 (вр.к-1120) и российского сорта листовой репы Селекта (вр.к-1371) повышена интенсивность фотосинтеза. Для условий загущения рекомендованы образцы пекинской капусты вр.к1375, Бице (вр.к-1376), китайской капусты к-647, для загущенного выращивания при малом расстоянии между стеллажами - китайской капусты Extra Dwarf Pack Choi (вр.к-1405) и розеточной капусты Хiao Ba Je Та Cai (к-695). Выявлены образцы пекинской капусты с очень высоким салатным качеством листьев - Chokurei (к-177), Tokyo Bekana (к-395), Zao Shi № 5 (вр.к-1120), Fun jen F1 (вр.к-1410). Полученные данные раскрывают некоторые особенности реакции различных генотипов капустных культур вида репа на изменение уровня освещенности и повышенную температуру. Морфофизиологическое разнообразие изученных форм позволит 
эффективнее управлять продукционным процессом в овощеводстве, а выявленные образцы могут привлекаться как источники ценных признаков при селекции специализированных сортов для сити-фермерства.

\section{ЛИТЕРАТУРА}

1. Пивоваров В.Ф., Старцев В.И. Капуста, ее виды и разновидности. М., 2006.

2. Plant factory: an indoor vertical farming system for efficient quality food production /T. Kozai, G. Niu, M. Takagaki (eds.). Academic Press, 2019.

3. Beacham A.M., Vickers L.H., Monaghan J.M. Vertical farming: a summary of approaches to growing skywards. The Journal of Horticultural Science and Biotechnology, 2019, 94(3): 277 (doi: 10.1080/14620316.2019.1574214).

4. Dou H., Niu G., Gu M., Masabni J. Morphological and physiological responses in Basil and Brassica species to different proportions of red, blue, and green wavelengths in indoor vertical farming. Journal of the American Society for Horticultural Science, 2020, 145(4): 267-278 (doi: 10.21273/JASHS04927-20).

5. Park J.E., Kim J., Purevdorj E., Son Y.J., Nho C.W., Yoo G. Effects of long light exposure and drought stress on plant growth and glucosinolate production in pak choi (Brassica rapa subsp. chinensis). Food Chemistry, 2021, 340: 128167 (doi: 10.1016/j.foodchem.2020.128167).

6. Baek M.W., Choi H.R., Solomon T., Jeong C.S., Lee O.H., Tilahun S. Preharvest methyl jasmonate treatment increased the antioxidant activity and glucosinolate contents of hydroponically grown pak choi. Antioxidants, 2021, 10(1): 131 (doi: 10.3390/antiox10010131).

7. Loconsole D., Cocetta G., Santoro P., Ferrante A. Optimization of LED lighting and quality evaluation of romaine lettuce grown in an innovative indoor cultivation system. Sustainability, 2019, 11(3): 841 (doi: 10.3390/su11030841).

8. Cartea M.E., Francisco M., Soengas P. Phenolic compounds in Brassica vegetables. Molecules, 2010, 16: 251-280 (doi: 10.3390/molecules16010251).

9. Голубкина Н.А., Сирота С.М., Пивоваров В.Ф., Яшин А.Я., Яшин Я.И. Биологически активные соединения овощей. М., 2010.

10. Соловьева А.Е., Артемьева А.М. Биохимические исследования коллекции капусты: традиции и перспективы. Труды по прикладной ботанике, генетике и селекции, 2012, 169: 137-146.

11. Podsędek A. Natural antioxidants and antioxidant capacity of Brassica vegetables: A review. $L W T$ Food Science and Technology, 2007, 40(1): 1-11 (doi: 10.1016/j.lwt.2005.07.023).

12. Al-Kodmany K. The vertical farm: a review of developments and implications for the vertical city. Buildings, 2018, 8(2): 24 (doi: 10.3390/buildings8020024).

13. Shamshiri R.R., Kalantari F., Ting K.C., Thorp K.R., Hameed I.A., Weltzien C., Ahmad D., Shad Z.M. Advances in greenhouse automation and controlled environment agriculture: a transition to plant factories and urban agriculture. International Journal of Agricultural and Biological Engineering (Beijing), 2018, 11(1): 1-22 (doi: 10.25165/j.ijabe.20181101.3210).

14. Alexandratos N., Bruinsma J. World agriculture towards 2030/2050: the 2012 revision. ESA Working Paper No. 12-03. Rome, FAO, 2012 (doi: 10.22004/ag.econ.288998).

15. FAO. 2019. FAO framework for the Urban Food Agenda. Rome, 2019 (doi: 10.4060/ca3151en).

16. Колпаков Н.А., Решетникова И.М. Сравнительная оценка сортообразцов салата-латука при разных сроках выращивания на гидропонике. Гавриш, 2012, 6: 10-12.

17. Колпаков Н.А., Чернышева Н.Н., Федорова М.И., Буркова Е.В., Вол Ю.С. Сравнительная оценка сортов и гибридов овощных культур в защищенном грунте. Вестник Алтайского ГАУ, 2015, 12(134): 5-9.

18. Полякова М.Н., Мартиросян Ю.Ц., Диловарова Т.А., Кособрюхов А.А. Фотосинтез и продуктивность у растений базилика (Ocimum basilicum L.) при облучении различными источниками света. Сельскохозяйственная биология, 2015, 50(1): 124-130 (doi: 10.15389/agrobiology.2015.1.124rus).

19. Кулешова Т.Э., Черноусов И.Н., Удалова О.Р., Аникина Л.М., Хомяков Ю.В., Александров А.В., Середин И.С., Феофанов С.В., Щеглов С.А., Галль Н.Р., Панова Г.Г. Влияние спектральных особенностей световой среды на поглощение света листьями салата и его нетто-продуктивность. Биофизика, 2020, 65: 112-124 (doi: 10.31857/S0006302920010147).

20. Olle M., Virsile A. The effects of light-emitting diode lighting on greenhouse plant growth and quality. Agricultural and Food Science, 2013, 22(2): 223-234 (doi: 10.23986/afsci.7897).

21. Lin K.H., Huang M.Y., Huang W.D., Hsu M. H., Yang Z. W., Yang, C. M. The effects of red, blue, and white light-emitting diodes on the growth, development, and edible 224 quality of hydroponically grown lettuce (Lactuca sativa L. var. capitata). Scientia Horticulturae, 2013, 150: 86-91 (doi: 10.1016/j.scienta.2012.10.002).

22. Li H., Tang C., Xu Z., Liu X., Han X. Effects of different light sources on the growth of non- 
heading Chinese cabbage (Brassica campestris L.). Journal of Agricultural Science, 2012, 4: 262 273 (doi: 10.5539/jas.v4n4p262).

23. Qian H., Liu T., Deng M., Miao H., Cai C., Shen W., Wang Q. Effects of light quality on main health-promoting compounds and antioxidant capacity of Chinese kale sprouts. Food Chemistry, 2016, 196: 1232-1238 (doi: 10.1016/j.foodchem.2015.10.055).

24. Панова Г.Г., Удалова О.Р., Канаш Е.В., Галушко А.С., Кочетов А.А., Прияткин Н.С., Архипов М.В., Черноусов И.Н. Основы физического моделирования «идеальных» агроэкосистем. Журнал технической физики, 2020, 90(10): 1633-1639 (doi: 10.21883/JTF.2020.10.49792.429-19).

25. Панова Г.Г., Черноусов И.Н., Удалова О.Р., Александров А.В., Карманов И.В., Аникина Л.М., Судаков В.Л., Якушев В.П. Научно-технические основы круглогодичного получения высоких урожаев качественной растительной продукции при искусственном освещении. Доклады Российской академии сельскохозяйственных наук, 2015, 4: 17-21.

26. Ермаков Е.И., Желтов Ю.И., Мильто Н.Е., Кучеров В.И. Почвогрунт для выращивания растений «Агрофит». Патент на изобретение РФ 2081555 (РФ) МПК А 01 G 9/10. Заявл. 13.07.1993. Опубл. 20.06.1997. Бюл. № 17.1997.

27. Боос Г.В., Джохадзе Т.И., Артемьева А.М., Кривченко В.И., Симон А.М., Тимошенко 3.В., Петровская Н.Н., Власова Э.А., Барашкова Э.А., Синельникова В.Н., Барашкова Э.А., Ивакин А.П., Ермаков А.И., Воскресенская В.В. Методические указания по изучению и поддержанию мировой коллекции капусты. СПб, 1988.

28. Лутова Л.А., Проворов Н.А., Тиходеев О.Н., Тихонович И.А., Ходжайова Л.Т., Шишкова С.О. Генетика развития растений. СПб, 2000.

29. Артемьева А.М., Соловьева А.Е., Беренсен Ф.А., Кочерина Н.В., Чесноков Ю.В. Экологогенетическая изучение морфологических и биохимических признаков качества у образцов Brassica rapa L. коллекции ВИР. Сельскохозяйственная биология, 2017, 52(1): 129-142 (doi: 10.15389/agrobiology.2017.1.129rus).

30. Доноры и источники для селекции листовых овощных культур вида Brassica rapa L. Kaталог мировой коллекции ВИР /Сост. А.М. Артемьева. СПб, 2004.

31. Ван Ц. Морфофизиологические реакции на световые условия растений разных биоморф из рода Brassica L. Автореф. канд. дис. СПб, 2007.

32. Коняев Н.Ф. Математический метод определения площади листьев растений. Доклады ВАСХНИЛ, 1970, 9: 43-46.

33. Коняев Н.Ф. Научные основы высокой продуктивности овощных растений. Новосибирск, 1978.

34. Николенко В.В., Котов С.Ф. Метод определения площади листовой поверхности декоративных сортов земляники. Экосистемы, их оптимизация и охрана, 2010, 2: 99-105.

35. Киселева Н.С. Способ вычисления площади листа груши по линейным измерениям с помощью расчетных коэффициентов и методов вариационной статистики. Сельскохозяйственная биология, 2017, 52(2): 211-217 (doi: 10.15389/agrobiology.2017.1.211rus).

36. Weiguo F., Pingping L., Yanyou W., Jianjian T. Effects of different light intensities on antioxidative enzyme activity, quality and biomass in lettuce. Horticultural Science, 2012, 39(3): 129134 (doi: 10.17221/192/2011-HORTSCI).

37. Fu Y., Li H., Yu J., Liu H., Cao Z., Manukovsky N.S., Liu H. Interaction effects of light intensity and nitrogen concentration on growth, photosynthetic characteristics and quality of lettuce ( $\mathrm{Lac}$ tuca sativa L. var. youmaicai). Scientia Horticulturae, 2017, 214: $51-57$ (doi: 10.1016/j.scienta.2016.11.020).

38. Viršilè A., Brazaitytė A., Vaštakaitė-Kairienè V., Jankauskienė J., Miliauskienė J., Samuolienè, G., Duchovskis P. Nitrate, nitrite, protein, amino acid contents, and photosynthetic and growth characteristics of tatsoi cultivated under various photon flux densities and spectral light compositions. Scientia Horticulturae, 2019, 258: 108781 (doi: 10.1016/j.scienta.2019.108781).

39. Hao X., Jia J., Mi J., Yang S., Khattak A. M., Zheng L., Wang M. An optimization model of light intensity and nitrogen concentration coupled with yield and quality. Plant Growth Regulation, 2020, 92(2): 319-331 (doi: 10.1007/s10725-020-00641-0).

40. Zanewich K.P., Rood S., Southworth C.E., Williams P.H. Dwarf mutants of Brassica: responses to applied gibberellins and gibberellin content. Journal of Plant Growth Regulation, 1991, 10(1): 121-127 (doi: 10.1007/BF02279323).

\section{1 ФГБНУ ФИЦ Всероссийский институт}

генетических ресурсов растений им. Н.И. Вавилова, 190000 Россия, г. Санкт-Петербург, ул. Большая Морская, 42-44, e-mail: akme11@yandex.ru $\square$;

${ }^{2}$ ФГБНУ Агрофизический научно-исследовательский институт,

195220 Россия, г. Санкт-Петербург, Гражданский просп., 14, e-mail: sinad@inbox.ru,gpanova@agrophys.ru,yuv_chesnokov@agrophys.ru

Поступила в редакцию 12 мая 2020 года 


\title{
BIOLOGICAL FEATURES OF Brassica rapa L. VEGETABLE LEAFY CROPS WHEN GROWING IN AN INTENSIVE LIGHT CULTURE
}

\author{
A.M. Artemyeva1, $2 \bowtie$, N.G. Sinyavina ${ }^{2}$, G.G. Panova ${ }^{2}$, Yu.V. Chesnokov \\ ${ }^{1}$ Federal Research Center Vavilov All-Russian Institute of Plant Genetic Resources, 42-44, ul. Bol'shaya Morskaya, St. \\ Petersburg, 190000 Russia, e-mail akme11@yandex.ru ( $\square$ corresponding author); \\ ${ }^{2}$ Agrophysical Research Institute, 14, Grazhdanskii prosp., St. Petersburg, 195220 Russia, e-mail sinad@inbox.ru, \\ gpanova@agrophys.ru, yuv_chesnokov@agrophys.ru \\ ORCID: \\ Artemyeva A.M. orcid.org/0000-0002-6551-5203 \\ Sinyavina N.G. orcid.org/0000-0003-0378-7331 \\ Panova G.G. orcid.org/0000-0002-1132-9915 \\ Chesnokov Yu.V. orcid.org/0000-0002-1134-0292
}

The authors declare no conflict of interests

Received May 12, 2020

doi: 10.15389/agrobiology.2021.1.103eng

\section{Abstract}

One of the main components of the successful production of plant products is the choice of crops with a high realization of their production potential under the formed conditions, including in the conditions of intensive light culture. The problem of compensating or eliminating the deficit of green crops is currently quite acute in Russia and in the world. The genetic diversity of the most widespread green brassicas plants of the species Brassica rapa L. for use in protected ground facilities has developed in Southeast Asia and includes numerous morphotypes of Chinese cabbage, pakchoi, tatsoi, wutacai, mizuna, and leafy turnip. In Russia, leafy B. rapa vegetables are used to a limited extent, mainly as salad vegetables. The main areas of $B$. rapa crops breeding for artificial light culture include a high growth rate (the duration of vegetative period is not more than 28-35 days, depending on the biological characteristics of the crop), the yield is not less than $3-8 \mathrm{~kg} / \mathrm{m}^{2}$, depending on crops, a certain compact plant habit, high quality of leaves, valuable biochemical composition, resistance to early bolting, resistance to possible low light and high air temperature, suitability for growing in a thin layer of soil or hydroponics. The biological features of the diversity of B. rapa leafy crops as sources for breeding for intensive light culture conditions have not been sufficiently studied, first of all, this concerns little-known crops (tatsoi, wutacai, mizuna) and certain morphotypes within common crops (Chinese cabbage and pakchoi). In this study, for the first time, we studied the wide genetic diversity from the Russian worldwide B. rapa collection of the Russian Federation, stored in the VIR, and morphotypes within them (72 accessions), including genotypes contrasting in morphological characteristics, under different supply light intensity for the development of energy-saving agro-technologies in intensive light culture. For the first time, correction factors were determined for calculating the leaf surface area from easily measured linear dimensions for each studied crop and type of leaves, which will speed up the calculations of photosynthesis characteristics. A different degree of variation in the variability of the size and weight of plants of various crops, depending on the illumination, is shown, the highest in Chinese cabbage and leafy turnip. It was found that the intensity of the light regime is largely determined the increase in the productivity of plants of all studied crops, mostly of Chinese cabbage and pakchoi and leafy turnip. High-yielding accessions of Chinese cabbage, pakchoi and leafy turnip were identified (more than $6.3 \mathrm{~kg} / \mathrm{m}^{2}$ for 28 days of growing season). The studied accessions of wutacai and mizuna are low-yielding and have a longer growing season, but are of interest as vegetables for functional nutrition and for decorative purposes. Semi-cabbage types of Chinese cabbage (Shantung, Santo, Xiao), which are of primary interest for light culture, have been identified. We recommend Chinese cabbage accessions vr.k-1375, Bice (vr.k-1376), and pakchoi k-647 for thickened cultivation,, and pakchoi Extra Dwarf Pack Choi (vr.k-1405 ) and tatsoi Xiao Ba Je Ta Cai (k-695) for growing with a small distance between the shelves of $25 \mathrm{~cm}$. Accessions of Chinese cabbage Chokurei (k-177), Tokyo Bekana (k-395), Zao Shi No. 5 (vr.k-1120), and Fun jen F1 (vr.k-1410) showed the highest salad qualities of the leaves. Under the conditions of a biopolygon, we managed to determine accessions with a stable manifestation of the traits, of early maturity and high productivity, practically independent of light intensity. These are accessions of Chinese cabbage Harumaki Shin Santousai (k-270), Tokyo Bekana (k-395), Xiaobaikou (k-74), pakchoi Kangre 605 (vr.k-1131), Gai Lang Jin Pin 25 F1 (vr.k-1124). In addition, it was shown that the Chinese accession of Chinese cabbage Zao Shi No. 5 (vr.k-1120) and the Russian cultivar of the leafy turnip Selecta (vr.k-1371) have increased the activity of the photosynthetic apparatus. The obtained data on the crops in general and the determined accessions of $B$. rapa are of interest for the practice of vegetable growing, in the development of elements of cultivar technology of $B$. rapa crops under conditions of light culture and as sources of valuable traits in breeding programs, including the development of city farming.

Keywords: Brassica rapa L., leafy crops, controlled-environment agriculture, artificial lighting, valuable traits, genetic sources. 